\title{
Thermal Comfort Characteristics and Its Effects on Health Status of Occupants of Residential Building Typology in a Sub-Humid Tropical Climate
}

\author{
Douye Pereere Wodu' ${ }^{1}$, Vincent Ezikornwor Weli1 ${ }^{10}$, Moses Okemini Nwagbara ${ }^{2}$ \\ ${ }^{1}$ Department of Geography and Environmental Management, University of Port-Harcourt, Choba, Port Harcourt, Nigeria \\ ${ }^{2}$ Department of Soil Science and Meteorology, Michael Okpara University of Agriculture, Umudike, Abia State, Nigeria \\ Email: welivinezi@yahoo.com
}

How to cite this paper: Wodu, D.P., Weli, V.E. and Nwagbara, M.O. (2020) Thermal Comfort Characteristics and Its Effects on Health Status of Occupants of Residential Building Typology in a Sub-Humid Tropical Climate. Atmospheric and Climate Sciences, 10, 258-271.

https://doi.org/10.4236/acs.2020.102014

Received: February 24, 2020

Accepted: April 24, 2020

Published: April 27, 2020

Copyright $\odot 2020$ by author(s) and Scientific Research Publishing Inc. This work is licensed under the Creative Commons Attribution International License (CC BY 4.0).

http://creativecommons.org/licenses/by/4.0/

cC) (i) Open Access

\begin{abstract}
This study examined the indoor thermal comfort characteristics and it implications for the health of the inhabitants in Yenagoa, Bayelsa state, Nigeria. The study used the experimental and survey research designs to gather primary data of temperature (dry and wet bulb), and perception of the inhabitants regarding thermal conditions in the study area. The effective temperature equation was used to determine the thermal comfort characteristics of the residential buildings in the study area, while the analysis of variance (ANOVA) model was used to determine the spatial variation in thermal comfort characteristics across the different land uses in the study area. The findings of the study include: the thermal comfort characteristics for the study area ranged between 27.3 ET \& $29.08 \mathrm{ET}$ at the dry period and at wet period 25.6 ET and 27.10 ET. The ANOVA model was significant at $\mathrm{P}<0.05$ (F-118.23, sig-0.00), indicating that there is a significant difference in the thermal comfort characteristics in the study area. The Duncan statistics however, revealed that, the GRA is the coolest when it comes to effective temperature. Furthermore, the respondents identified that; the period of discomfort is mostly afternoon (37.3\%) and Nights (35.1\%). Health problems as a result of poor thermal conditions include skin rashes (59.8\%), heat cramps (26.4\%), prickly heat (42\%) and heat exhaustion (51.3\%). As a result of the findings the study strongly advocates, building residential buildings with several openings and locating such openings in recognition of the wind direction.
\end{abstract}

\section{Keywords}

Thermal-Comfort, Residential Building, Effective-Temperature, Tropical 


\section{Introduction}

Globally, shelter remains one of the top priorities for government of nations. This is so not only because, buildings are needed to protect lives, but also people need to rest after a hard days' work. Furthermore, buildings are needed to provide space for keeping the acquisitions (household properties) of persons. Therefore, shelter is an very improtant requirement with which to settle people in any environment. However, for any building to be effective for use by humans, the indoor thermal conditions must be satisfactory [1] [2] [3] [4] [5].

Nevertheless, the first factor that is considered when building in the developed world is how much comfort a proposed building will have on people who are to dwell therein, and with such comfort not realised using additional cost with energy. Therefore, buildings are designed in such a way that, comfort is given maximum attention, before considering the aesthetic characteristics of the building. In such climes, the meteorological conditions and other environmental factors are considered when designing buildings. Experts trained in the skill of building, and interpreting plans are employed from the design phase to the interpretation, through the completion. As such the thermal conditions of buildings in the developed world are tolerated by the inhabitants [6] [7].

In the developing world, the case is not the same. Building designs are borrowed from totally different climates and built here. Persons who have no skill in building construction are contracted to build houses, just to avert cost. As a result, buildings are not properly thought through and by implication impacting the indoor temperature characteristics. Similarly, most private investors are in the real estate business to make profit, not bordering what the implication of their actions would be for the persons that will rent or lease such buildings. This has not been helped by the land rent which is so high in urban centres of the developing world, which continues to force the land owners to maximize the land space they have for building purposes. The situation in Yenagoa properly fits into the above stated problems. Moreso, economic consideration mostly limits the type of buildings..., economic consideration mostly determines the type of buildings that are built rather than, the comfort that such buildings ought to generate for the occupants. Similarly, buildings are not built according to standards, and where they are built to standard, the cost to rent them is usually too high to afford. The implication is that people are forced to dwell in buildings that they ordinarily won't inhabit. Apart from stress, health problems also emanate from thermal discomfort. Several studies have looked at the indoor and outdoor thermal comfort conditions in the past [7]-[17] but none to the best of the knowledge of the researchers, have looked at the health effect of thermal comfort for building occupants. This study assessed the thermal comfort characteristics and its effects on health of residents in residential building types in Yenagoa, Bayelsa state. 


\section{Materials and Methods}

\subsection{Study Area}

This research was conducted in Yenagoa, being the capital city of Bayelsa state. It is located on Latitude $4^{\circ} 52^{\prime} \& 4^{\circ} 58^{\prime} \mathrm{N}$, and longitude $6^{\circ} 16^{\prime} \& 6^{\circ} 20^{\prime} \mathrm{E}$ (Figure 1 ). The city is $21,110 \mathrm{~km}^{2}$ in size (Google earth, 2016). To the North the area is delimited by Kolokuma/Opokuma LGA, South by Southern-Ijaw LGA, at the North-west by Sagbama LGA and to the East by Ogbia LGA [18].

The area located in the tropical setting that is characterised by the tropical rain forest climate type of the [19]. The climate of the study area is determined by two principal air masses, namely, Tropical Maritime Air-mass (mT) and Tropical Continental Air-mass (cT). These combined influence the seasons in the study environment, (which are the wet and dry seasons). Recently, however, research [20] has revealed that there is no distinct dry period in the area as all months have an average rainfall amount of $0.25 \mathrm{~mm}$. However, the anthropogenic activities in the area in recent decades which is an exodus from the discovery and mining of crude oil in the area has resulted in the emission of GHGs, deforestation, and the altering of the original climate of the study area [20]. As a result, the building comfort characteristics in the area, are already greatly affected, and by extension could affect health if not ameliorated or averted.

\subsection{Methods}

The research design adopted for this study is the experimental and survey research designs design. Furthermore, the primary data were used for the study and included data obtained from daily reading of the wet bulb and dry bulb

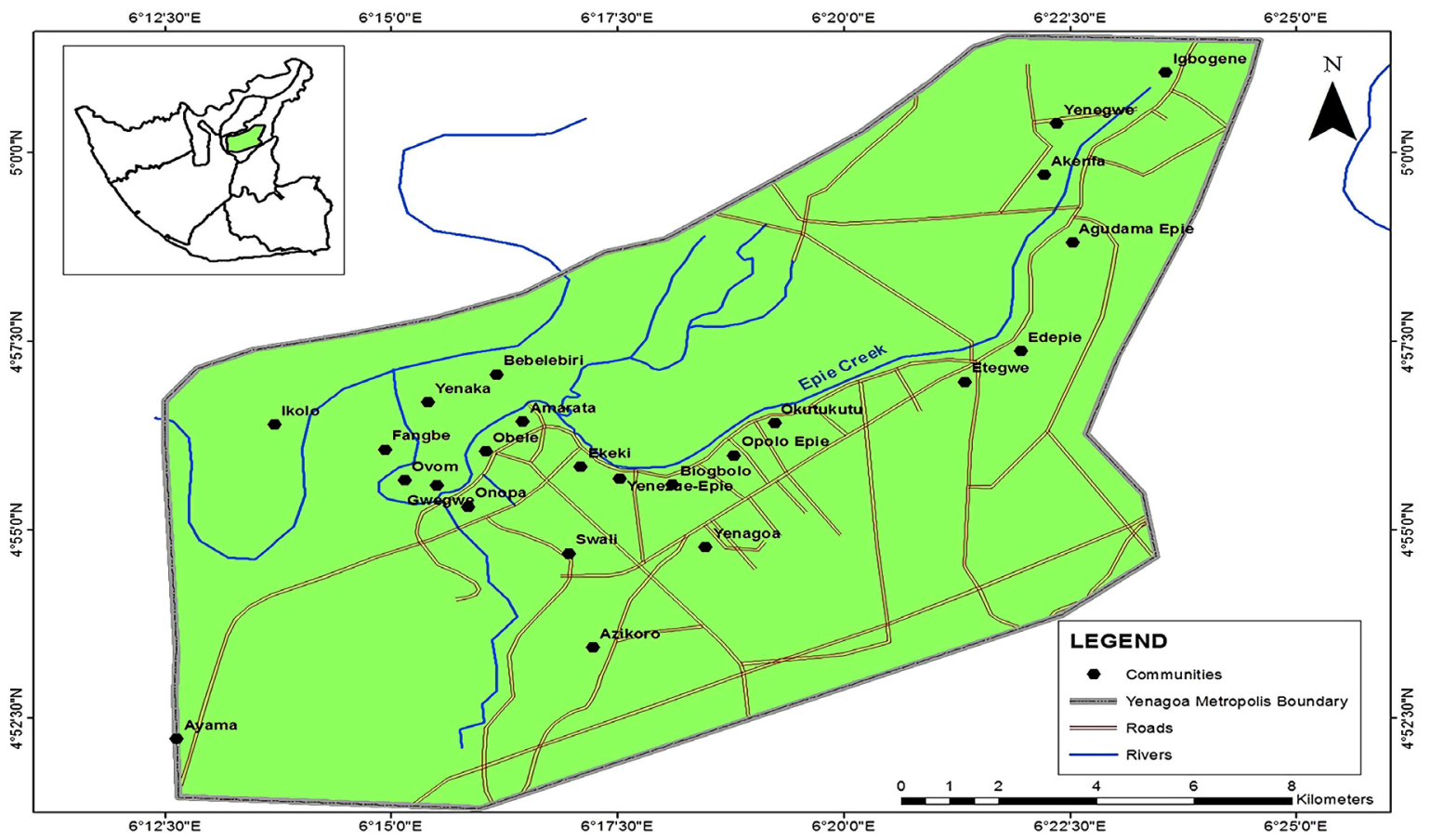

Figure 1. Yenagoa showing major communities. 
thermometers situated at the sample points. Similarly, questionnaire copies were used to generate information regarding the perceived health effect of indoor thermal comfort in the area. Furthermore, the study adopted the stratified sampling technique to delineate 5 zones using the land-use as the determinant. As a result, the researchers derived five land-uses that are listed as below:

1) Residential areas;

2) Industrial areas;

3) Commercial areas;

4) Governmental (GRA);

5) Mixed uses.

This method of calibration has been used by [21] [22] [23], and [14]. About 20 neighbourhoods were delineated in the study area (see Table 1). Within each neighbourhood, all existing streets (598 in number) which are registered with the urban development authority were given identification numbers. Using a systematic random sampling technique, every 3 rd street was slected to achieve the objective of the study.

The calibration in Table 1 implies that $33.33 \%$ of registered streets are sampled. After selecting the streets, 3 houses (Bungalows only) were selected based on predetermined classification of housing type (Table 2). Therefore a total of 597 houses were selected for the study ( 3 in every street).

For the daily reading of the wet $\&$ dry bulb thermometers, the living rooms

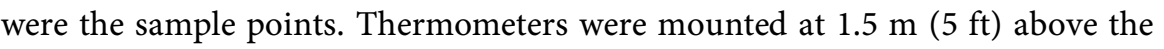
floor for the purpose of uniformity and a scientific approach to data acquisition. Again the standard has been suggested by world meteorological organisation (WMO). This method has been used by [14] and reasonable success was realised.

Table 1. Neighborhoods in the study area and the number of streets sampled.

\begin{tabular}{|c|c|c|c|c|}
\hline Zones & Areas & $\begin{array}{l}\text { Number of } \\
\text { streets }\end{array}$ & $\begin{array}{c}\text { Number of } \\
\text { sampled streets }\end{array}$ & $\begin{array}{c}\text { Number of houses } \\
\text { to be sampled }\end{array}$ \\
\hline A & Agudama, Akenpai, Biogbolo, NIIT & $246 / 3$ & 82 & 246 \\
\hline $\mathrm{B}$ & Bayelsa-Palm, Gbarantoru, Imiringi & $17 / 3$ & 6 & 116 \\
\hline $\mathrm{C}$ & $\begin{array}{l}\text { Tombia Round-about, Ede-Epe, } \\
\text { Amarata, Swali, Imgbi, Ekeki } 1\end{array}$ & $168 / 3$ & 56 & 168 \\
\hline $\mathrm{D}$ & Commissioners Qurts, Opolo, G.R.A & $54 / 3$ & 18 & 54 \\
\hline $\mathrm{E}$ & Arieta-line, Kpansia, Okaka, Igbogene & $113 / 3$ & 37 & 113 \\
\hline Total & & 598 & 199 & 597 \\
\hline
\end{tabular}

Table 2. Building types in Yenagoa.

\begin{tabular}{cl}
\hline Building type & \multicolumn{1}{c}{ Characteristic } \\
\hline 1 & $\begin{array}{l}\text { Stone coated roof, parapet, Pop ceiling, window (casement, Single Hung, Bay, } \\
\text { Awning, Arched), ceramic floor tiles }\end{array}$ \\
2 & $\begin{array}{l}\text { Long spam roofing sheets, PVC ceilings, sliding windows, } \\
\text { ceramic/cement/rug/plastic carpet floors. }\end{array}$ \\
& $\begin{array}{l}\text { Metal zinc/Asbestos roof, louvers/wooden windows, cement/terrazzo floor, } \\
\text { asbestos ceilings }\end{array}$ \\
\hline
\end{tabular}


The dwelling units sampled were the buildings without air conditioning systems (AC) (i.e. naturally ventilated buildings).

Before the readings of the hygrometer and the maximum and minimum thermometer were done in all the sample points, the instruments were made to stay for 5 minutes, a time-frame within which the instruments could get adapted to the climatic condition of the particular sample point. This condition is known as the process of standardization of the instrument. This process has been applied by [15] [20] and was effective. The measurements of the parameters for the study were carried out at climatological hours (00:00 hrs, 6:00 hrs, 12:00 hrs, and 18:00 hrs) for a period of one year.

The effective temperature index (ET) (Equation (1)) was used to determine the comfort level of the dwelling units as suggested by [24].

$$
\mathrm{ET}=0.4(\mathrm{Td}+\mathrm{Tw})+4.8
$$

Hence an ET value of $18.9^{\circ} \mathrm{C}$ or below indicates cold stress, while an ET value of above $25.6^{\circ} \mathrm{C}$ reveals heat stress [14] [24]. The data were analysed using analysis of variance (ANOVA). The ANOVA analysis was carried out in the IBM/SPSS v 22 environment.

\section{Results}

Table 3 shows the effective temperature characteristics for the different building

Table 3. Effective temperature characteristics in the different building types in Yeanagoa.

\begin{tabular}{|c|c|c|c|c|c|c|c|}
\hline \multirow{2}{*}{ Land use types } & \multirow{2}{*}{ Building types - } & \multicolumn{6}{|c|}{ Effective temperature in ${ }^{\circ} \mathrm{C}$} \\
\hline & & 00:00 & $6: 00$ & $12: 00$ & 18:00 & Wet period & Dry period \\
\hline \multirow{3}{*}{ Residential } & 1 & 26.33 & 25.72 & 27.01 . & 28.74 & 25.5 & 30.49 \\
\hline & 2 & 26.21 & 25.64 & 27.51 & 28.59 & 25.31 & 30.34 \\
\hline & 3 & 26.04 & 25.42 & 26.04 & 28.39 & 24.84 & 30.14 \\
\hline \multirow{3}{*}{ Industrial } & 1 & 26.89 & 25.92 & 26.82 & 29.34 & 25.42 & 31.09 \\
\hline & 2 & 26.73 & 25.84 & 26.75 & 29.29 & 25.34 & 31.04 \\
\hline & 3 & 26.51 & 25.69 & 26.53 & 28.92 & 25.19 & 30.67 \\
\hline \multirow{3}{*}{ Commercial } & 1 & 27.23 & 25.89 & 26.83 & 28.94 & 25.39 & 30.69 \\
\hline & 2 & 27.34 & 25.82 & 26.73 & 28.72 & 25.32 & 30.47 \\
\hline & 3 & 26.91 & 25.76 & 26.41 & 28.54 & 25.26 & 30.29 \\
\hline \multirow{3}{*}{ Governmental } & 1 & 26.36 & 25.81 & 26.38 & 28.79 & 25.31 & 30.54 \\
\hline & 2 & 26.28 & 25.73 & 26.31 & 28.48 & 25.23 & 30.23 \\
\hline & 3 & 26.09 & 25.69 & 26.17 & 28.27 & 25.19 & 30.02 \\
\hline \multirow{3}{*}{ Mixed } & 1 & 26.70 & 25.69 & 26.76 & 28.95 & 25.19 & 30.70 \\
\hline & 2 & 26.64 & 25.58 & 26.69 & 28.77 & 25.08 & 30.52 \\
\hline & 3 & 26.39 & 25.51 & 26.54 & 28.53 & 25.01 & 30.28 \\
\hline
\end{tabular}

N.B: building types are as defined. 1. Stone coated roof, parapet, Pop ceiling, window (casement, Single Hung, Bay, Awning, Arched), ceramic floor tiles; 2. Long spam roofing sheets, PVC ceilings, sliding windows, ceramic/cement/rug/plastic carpet floors; 3. Metal zinc/Asbestos roof, louvers/wooden windows, cement/terrazzo floor, asbestos ceilings. 
types in the study area. In the table one thing is lucid and that is that, the effective temperature characteristics indicated that the thermal conditions in the area fell below the threshold for which indoor comfort can be experienced. However, the period 6:00 hrs, where some of the housing types had an effective temperature value less than $25.6^{\circ} \mathrm{C}$. Nevertheless, in the residential area, building type 1 recorded the highest ET value at the period 18:00 with ET value of $28.7^{\circ} \mathrm{C}$; while the lowest ET was recorded at the 6:00 hrs with ET value of $25.7^{\circ} \mathrm{C}$. In building type 2 the highest ET value at the period 18:00 with ET value of $28.6^{\circ} \mathrm{C}$; while the lowest ET was recorded at the 6:00 hrs with ET value of $25.6^{\circ} \mathrm{C}$. Whereas in the wet period an ET value of $25.5^{\circ} \mathrm{C}$ was recorded, while the dry period $30.3^{\circ} \mathrm{C}$. In the building type 3 the highest ET value at the period 18:00 with ET value of $28.4^{\circ} \mathrm{C}$; while the lowest ET was recorded at the $6: 00 \mathrm{hrs}$ with ET value of $25.4^{\circ} \mathrm{C}$. Whereas in the wet period an ET value of $24.84^{\circ} \mathrm{C}$ was recorded, while the dry period $30.1^{\circ} \mathrm{C}$.

In the industrial area, building type 1 recorded the highest ET value at the period 18:00 with $\mathrm{ET}$ value of $29.3^{\circ} \mathrm{C}$; while the lowest $\mathrm{ET}$ was recorded at the 6:00 hrs with ET value of $25.9^{\circ} \mathrm{C}$. Whereas in the wet period an ET value of $25.4^{\circ} \mathrm{C}$ was recorded, in the dry period ET of $31.9^{\circ} \mathrm{C}$ was recorded. Building type 2 recorded the highest ET value at the period $18: 00$ with ET value of $29.2^{\circ} \mathrm{C}$; while the lowest ET was recorded at the $6: 00 \mathrm{hrs}$ with ET value of $25.8^{\circ} \mathrm{C}$. Whereas in the wet period an ET value of $25.3^{\circ} \mathrm{C}$ was recorded, in the dry period ET of $31.4^{\circ} \mathrm{C}$ was recorded. Building type 3 recorded the highest ET value at the period 18:00 with ET value of $28.9^{\circ} \mathrm{C}$; while the lowest ET was recorded at the 6:00 hrs with ET value of $25.6^{\circ} \mathrm{C}$. Whereas in the wet period an ET value of $25.1^{\circ} \mathrm{C}$ was recorded, in the dry period ET of $30.7^{\circ} \mathrm{C}$ was recorded.

In the commercial land use, building type 1 recorded the highest ET value at the period 18:00 with ET value of $28.9^{\circ} \mathrm{C}$; while the lowest ET was recorded at the 6:00 hrs with ET value of $25.8^{\circ} \mathrm{C}$. Whereas in the wet period an ET value of $25.3^{\circ} \mathrm{C}$ was recorded, in the dry period ET of $30.7^{\circ} \mathrm{C}$ was recorded. Building type 2 recorded the highest ET value at the period 18:00 with ET value of $28.7^{\circ} \mathrm{C}$; while the lowest ET was recorded at the $6: 00 \mathrm{hrs}$ with ET value of $25.82^{\circ} \mathrm{C}$. Whereas in the wet period an ET value of $25.3^{\circ} \mathrm{C}$ was recorded, in the dry period ET of $30.5^{\circ} \mathrm{C}$ was recorded. Building type 3 recorded the highest ET value at the period 18:00 with ET value of $28.54^{\circ} \mathrm{C}$; while the lowest ET was recorded at the 6:00 hrs with ET value of $25.76^{\circ} \mathrm{C}$. Whereas in the wet period an ET value of $25.26^{\circ} \mathrm{C}$ was recorded, in the dry period $\mathrm{ET}$ of $30.3^{\circ} \mathrm{C}$ was recorded.

In the GRA land use, building type 1 recorded the highest ET value at the period 18:00 with ET value of $28.79^{\circ} \mathrm{C}$; while the lowest ET was recorded at the 6:00 hrs with ET value of $25.81^{\circ} \mathrm{C}$. Whereas in the wet period an ET value of $25.3^{\circ} \mathrm{C}$ was recorded, in the dry period ET of $30.5^{\circ} \mathrm{C}$ was recorded. Building type 2 recorded the highest ET value at the period 18:00 with ET value of $28.4^{\circ} \mathrm{C}$; while the lowest ET was recorded at the $6: 00 \mathrm{hrs}$ with ET value of $25.7^{\circ} \mathrm{C}$. Whereas in the wet period an ET value of $25.2^{\circ} \mathrm{C}$ was recorded, in the dry period 
$\mathrm{ET}$ of $30.5^{\circ} \mathrm{C}$ was recorded. Building type 3 recorded the highest ET value at the period 18:00 with ET value of $28.3^{\circ} \mathrm{C}$; while the lowest ET was recorded at the 6:00 hrs with ET value of $25.6^{\circ} \mathrm{C}$. Whereas in the wet period an ET value of $25.1^{\circ} \mathrm{C}$ was recorded, in the dry period ET of $30^{\circ} \mathrm{C}$ was recorded.

In the Mixed land use, building type 1 recorded the highest ET value at the period 18:00 with ET value of $28.9^{\circ} \mathrm{C}$; while the lowest ET was recorded at the 6:00 hrs with ET value of $25.7^{\circ} \mathrm{C}$. Whereas in the wet period an ET value of $25.2^{\circ} \mathrm{C}$ was recorded, in the dry period ET of $30.7^{\circ} \mathrm{C}$ was recorded. Building type 2 recorded the highest ET value at the period $18: 00$ with ET value of $28.7^{\circ} \mathrm{C}$; while the lowest ET was recorded at the $6: 00 \mathrm{hrs}$ with ET value of $25.6^{\circ} \mathrm{C}$. Whereas in the wet period an ET value of $25.1^{\circ} \mathrm{C}$ was recorded, in the dry period ET of $30.5^{\circ} \mathrm{C}$ was recorded. Building type 3 recorded the highest ET value at the period 18:00 with ET value of $28.5^{\circ} \mathrm{C}$; while the lowest ET was recorded at the 6:00 hrs with ET value of $25.5^{\circ} \mathrm{C}$. Whereas in the wet period an ET value of $25^{\circ} \mathrm{C}$ was recorded, in the dry period ET of $30.3^{\circ} \mathrm{C}$ was recorded.

Table 4 shows the variation in effective temperature in the different building types in Yenagoa. In the table, the model is significant at $\mathrm{P}<0.05$. Indicating that, there is a significant difference in the effective temperature reach at different times of the day in the study area.

Table 5 shows the Duncan statistics of the building typology with varying ET values. In the table, building type 3 appears to be the building type with the lowest $\mathrm{ET}$ value of $26.7^{\circ} \mathrm{C}$.

Table 4. Variation in effective temperature in the different building types in Yenagoa.

\begin{tabular}{cccccc}
\hline \multicolumn{7}{c}{ ANOVA } \\
\hline \multicolumn{7}{c}{ Effective_Temp_Var } \\
\hline & Sum of Squares & Df & Mean Square & F & Sig. \\
\hline Between Groups & 1067.123 & 2 & 424.003 & 118.2301 & 0.000 \\
Within Groups & $15,342.233$ & 447 & 53.504 & & \\
Total & $16,409.356$ & 449 & & & \\
\hline
\end{tabular}

Table 5. Duncan statistics of the variation in the effective temperature of the various building types in Yenagoa.

\begin{tabular}{ccccc}
\hline \multicolumn{5}{c}{ Yenagoa_effectiveTemp } \\
\hline \multicolumn{5}{c}{ Duncan $^{\mathrm{a}}$} \\
\hline \multirow{2}{*}{ Building types } & $\mathrm{N}$ & \multicolumn{3}{c}{ Subset for alpha $=0.05$} \\
\cline { 3 - 5 } 3 & 150 & 26.7175 & 2 & \\
\hline 2 & 150 & & 26.9825 & 27.0574 \\
1 & 150 & & & 1.000 \\
\hline
\end{tabular}

Means for groups in homogeneous subsets are displayed. ${ }^{a}$ Uses Harmonic Mean Sample Size $=150.000$. 
The building type 2 is the building type with the second lowest mean ET value of $26.9^{\circ} \mathrm{C}$. However, the building type with the highest mean ET value is the building type 1 with mean ET value of $27^{\circ} \mathrm{C}$.

Table 6 shows the perception of residents satisfaction to their building characteristics in the study area. It was revealed that only $2 \%$ of the total respondents were undecided about the issue, while $56.9 \%$ of the total respondents suggested that they were not satisfied with their dwelling units. Similarly, the respondents that suggested that they were highly not satisfied with their building characteristics accounted for $19.6 \%$. However, those that were satisfied and highly satisfied with their building characteristics accounted for $19.8 \%$ and $1.8 \%$ respectively. The finding in this table points to the fact that the respondents are clearly not satisfied with the building characteristics in the study area. The analysis below further revealed important issues relating to perception of respondents and thermal confort.

However, Table 7 further showed the perception of indoor Thermal comfort characteristics of different thermal conditions in Yenagoa. The respondents emphasized that during the cold periods, the area is cold as suggested by $59.8 \%$ of

Table 6. Perception of indoor to the building characteristics of different thermal conditions in Yenagoa.

\begin{tabular}{ccc}
\hline Perception & Frequency & Percentage (\%) \\
Undecided & 9 & 2 \\
Not satisfied & 256 & 56.9 \\
Highly not satisfied & 88 & 19.6 \\
Satisfied & 89 & 19.8 \\
Highly satisfied & 8 & 1.8 \\
Total & 450 & 100 \\
\hline
\end{tabular}

Table 7. Thermal comfort characteristics in the study area.

\begin{tabular}{cccc}
\hline Perception & Comfort characteristics indoor & Frequency & Percentages \\
\hline \multirow{3}{*}{ Overall thermal satisfaction } & Very dissatisfied & 189 & 42 \\
& Dissatisfied & 115 & 25.6 \\
& Satisfied & 89 & 19.8 \\
& Very satisfied & 57 & 12.7 \\
& Total & 450 & 100 \\
During cold periods & Very cold & 14 & 3.1 \\
& Cold & 269 & 59.8 \\
& Normal & 167 & 37.1 \\
& Total & 450 & 100 \\
During hot periods & Very hot & 237 & 52.7 \\
& Hot & 114 & 25.3 \\
& Normal & 99 & 22 \\
& Total & 450 & 100 \\
\hline
\end{tabular}


the total respondents. The respondents that suggested that, the area is very cold in the cool periods, accounted for $3.1 \%$ of the total respondents. Again, the respondents that suggested that the area is normal during the cool periods, accounted for $37.1 \%$ of the total respondents. On the flip side that is during the dry periods $52.3 \%$ of the total respondents suggested that the area is very hot, while $25.3 \%$ of the respondents suggested that, the area is hot during the dry periods. However, $22 \%$ of the respondents suggested that the area is tolerable (normal) during the dry periods.

Table 8 identified the period of discomfort during day. In the table, none of the respondents indicated that they experienced thermal discomfort during the morning hours. However, during the afternoon period, as high as $37.3 \%$ of the respondents indicated that they feel discomfort during the afternoon hours and those that revealed that they feel discomfort during the evening periods accounted for $27.6 \%$ of the total respondents.

Table 9 is about the sleep experience of the respondents during the night times. From the table, it is evident that the majority of the respondents do not have good sleep at all in the night period. This is hinged on the fact that, $65.8 \%$ of the respondents indicated that they do not have good sleep at night.

The respondents that suggested that they have average sleep in the night time accounted for $25.1 \%$ of the total respondents in the study area. The respondents that indicated that they have good sleep in the night time were only $9.1 \%$ of the respondents.

Table 10 presented how frequent the respondents encounter skin rashes in the study area. What is lucid in the table is that, $59.8 \%$ of the respondents suggested that they experience the problem of skin rashes in the study area. Similarly, the respondents suggested that they experience heat rashes but seldom account for $37.8 \%$ of the total respondents. The respondents that reported that they have never experienced skin rashes accounted for $2.4 \%$ of the total respondents.

Table 8. Period of discomfort in the day.

\begin{tabular}{ccc}
\hline$\square$ Period & Frequency & Percentages \\
Morning & 00 & 00 \\
Afternoon & 168 & 37.3 \\
Evening & 124 & 27.6 \\
Nights & 158 & 35.1 \\
Total & 450 & 100 \\
\hline
\end{tabular}

Table 9. Sleep experience of the inhabitants during the night time.

\begin{tabular}{ccc}
\hline Experience & Frequency & Percentages \\
\hline Poor sleep & 296 & $\mathbf{6 5 . 8}$ \\
Average sleep & 113 & $\mathbf{2 5 . 1}$ \\
Good sleep & 41 & 9.1 \\
Total & 450 & 100 \\
\hline
\end{tabular}


Table 10. Frequency of appearance of skin rashes on the skin of inhabitants.

\begin{tabular}{ccc}
\hline Experience & Frequency & Percentages \\
\hline Often & 269 & $\mathbf{5 9 . 8}$ \\
Seldom & 170 & 37.8 \\
Never & 11 & $\mathbf{2 . 4}$ \\
Total & 450 & 100 \\
\hline
\end{tabular}

Table 11 showed the frequent of occurrence of heat cramps among respondents in Yenagoa. It was revealed that $26.4 \%$ of the respondents indicated that they often experience heat cramps. Similarly, $54.4 \%$ of the respondents revealed that they seldom experience heat cramps in the area. Furthermore, $19.1 \%$ of the respondents asserted that they have never experienced heat cramps in the area. This result is particularly not encouraging for the inhabitants of the study area, looking at the dangers that heat cramps portend for persons who experience it.

In Table 12, the respondent's frequency of experiencing prickly heat in the area is displayed. It was revealed that $42 \%$ of the respondents often experience prickly heat in Yenagoa. The respondents that expressed that they seldom experience prickly heat in the area accounted for $39.1 \%$ of; while those that revealed that they have never experienced the problem of prickly heat in the area, were only $18.9 \%$.

In Table 13, the respondents' perception of the problem of heat exhaustion was shown. It was reported that $25.8 \%$ of the respondents often experienced the problem of heat exhaustion in the area.

The respondents that said they seldom experienced the problem of heat exhaustion in the area accounted for $51.3 \%$ of the respondents. The respondents that indicated that, they have never experienced the problem of heat exhaustion, in the area accounted for $22.9 \%$.

Table 11. Frequency of incidence of heat cramps.

\begin{tabular}{ccc}
\hline Experience & Frequency & Percentages \\
\hline Often & 119 & 26.4 \\
Seldom & 245 & $\mathbf{5 4 . 4}$ \\
Never & 86 & 19.1 \\
Total & 450 & 100 \\
\hline
\end{tabular}

Table 12. Frequency of appearance of prickly heat.

\begin{tabular}{ccc}
\hline Experience & Frequency & Percentages \\
\hline Often & 189 & 42 \\
Seldom & 176 & 39.1 \\
Never & 85 & 18.9 \\
Total & 450 & 100 \\
\hline
\end{tabular}


Table 13. Frequency of incidence of heat exhaustion.

\begin{tabular}{ccc}
\hline Experience & Frequency & Percentages \\
\hline Often & 116 & 25.8 \\
Seldom & 231 & 51.3 \\
Never & 103 & 22.9 \\
Total & 450 & 100 \\
\hline
\end{tabular}

\section{Conclusion and Recommendation}

Generally, the effective (ET) values recorded and the spatial variation of it showed that, the building characteristics themselves have significant impact on the indoor thermal conditions as contemplated by [14]. These characteristics include the wall conditions (are they screeded or not), what colour of and type of paint used in the painting of the wall, the height of the fence (are they tall or they are low), materials used for the windows and whether there are mosquito nets and how many layers there are, the ventilation outlets and the oxygen recharge capacity of the buildings, how much properties are inside the building, the positioning of the windows and how many they are, the roof type and the materials used, etc. All these jointly affected the variation in Effective Temperature, in the study area. These, factors have also been identified by previous workers as determinants of thermal conditions in buildings [3] [5] [9] [25]. Energy Efficiency in Buildings, 2007 [2] [6] [8] [10] [11] [13] [26] [27] [28] [29] [30]. Nevertheless, seasons were also very important in determining the indoor thermal conditions. Reason for this is not farfetched, the area is coastal in orientation and is characterised by two tropical airmass types. When the tropical maritime airmass (mT) is prevailing over the area, rain is produced and by extension has some cooling effects on the thermal conditions, since the rains cools the outdoor conditions. The direct opposite is experienced when the tropical continental airmass (cT) prevails in the area.

In general, the respondents were not satisfied with the indoor thermal conditions in the study area. However, the respondents emphasized that during the cold periods, the area is cold this is as suggested by $59.8 \%$ of the total respondents. The respondents that suggested that, the area is very cold in the cool periods, accounted for $3.1 \%$ of the total respondents. Again, the respondents that suggested that the area is normal during the cool periods, accounted for $37.1 \%$ of the total respondents. On the flip side that is during the dry period $52.3 \%$ of the total respondents suggested that the area is very hot, while $25.3 \%$ of the respondents suggested that, the area is hot during the dry periods. However, 22\% of the respondents suggested that the area is tolerable (normal) during the dry periods. The period that respondents feel discomfort in the day is in the afternoon (37.3\%). Also unravelled is that the respondents have bad sleeping experience in the area. The major health challenges experienced by the respondents include; skin (59.8\%); heat cramps (54.4\%); prickly heat (42\%); heat exhaustion 
(51.3\%). Generally, these health challenges have been expressed in previous studies to be associated with poor building interpretation and planning [4] [7] [12] [16].

Nevertheless, the study concludes that, a more integrated research be carried out to include the evaluation of the impacts of the outdoor thermal cum climatological conditions on the indoor thermal conditions in the study area. This is a scope this current attempt did not cover. Notwithstanding, there is the need for constructing residential buildings with several openings and locating such openings in recognition of the wind direction and speed characteristics in the study area. Similarly, the study recommends that the government and the Association of Building Engineers (civil engineers) in the state, should identify and stop the operations of quacks in the building industry in the study area. The study finally recommends the synchronization of the building characteristics and the climate of the area.

\section{Conflicts of Interest}

The authors declare no conflicts of interest regarding the publication of this paper.

\section{References}

[1] Abotutu, A. and Ojeh, A. (2013) Structural Properties of Dwelling and Thermal Comfort in Tropical Cities: Evidence from Warri, Nigeria. International Journal of Science and Technology Bahir Dar, Ethiopia, 2, 67-98.

[2] Asadi, E., da Silva, M.G., Atunes, C.H. and Dias, L. (2011) Multi-Objective Optimization for Building Retrofit Strategies: A Model and an Application. Energy and Buildings, 44, 81-87. https://doi.org/10.1016/j.enbuild.2011.10.016

[3] ASHRAE Standard 55 (2004) Thermal Environmental Conditions for Human Occupancy. American Society of Heating, Refrigerating and Air-Conditioning Engineers, Inc., Atlanta.

[4] Beerepoot, M. and Beerepoot, N. (2014) Government Regulation as an Impetus for Innovation: Evidence from Energy Performance Regulation in the Dutch Residential Building Sector. Energy Policy, 35, 4812-4825.

https://doi.org/10.1016/j.enpol.2007.04.015

[5] Cheung, T., Schiavon, S., Parkinson, T., Li, P. and Brager, G. (2019) Analysis of the Accuracy on PMV-PPD Model Using the ASHRAE Global Thermal Comfort Database II. Building and Environment, 153, 205-217. https://doi.org/10.1016\%2Fj.buildenv.2019.01.055

[6] Simoni, M., Annesi-Maesano, I., Sigsgaard, T., Norback, D., Wieslander, G., Canciani, M., Sestini, P. and Viegi, G. (2010) School Air Quality Related to Dry Cough, Rhinitis and Nasal Patency in Children. European Respiratory Journal, 35, 742-749. https://doi.org/10.1183/09031936.00016309

[7] Spengler, J.D. and Chen, Q. (2000) Indoor Air Quality Factors in Designing a Healthy Building. Annual Review of Energy and the Environment, 25, 567-600. https://doi.org/10.1146/annurev.energy.25.1.567

[8] Khadijah, K. and Azimin, S.B. (2014) Thermal Comfort Assessment of a Classroom in Tropical Climate Conditions. Recent Advances in Energy, Environment and Development, 30, 87-91. 
[9] Kim, J.L., Elfman, L., Mi, Y., Johansson, M., Smedje, G. and Norback, D. (2005) Current Asthma and Respiratory Symptoms among Pupils in Relation to Dietary Factors and Allergens in the School Environment. Indoor Air, 15, 170-182. https://doi.org/10.1111/j.1600-0668.2005.00334.x

[10] Lawal, A. (2013) Climate Responsive Approach to Building Design for Comfort in Warm Humid Climate. International Journal of Engineering and Technology, 3, 50-58.

[11] Leth-Petersen, S. and Togeby, M. (2016) Demand for Space Heating in Apartment Blocks: Measuring Effects of Policy Measures Aiming at Reducing Energy Consumption. Energy Economics, 23, 387-403. https://doi.org/10.1016/S0140-9883(00)00078-5

[12] Myriam, B.C.A and Philomena, M.B. (2015) Climate Change Consequences for the Indoor Environment. Building Physics and Systems, the Netherlands Organisation for Applied Scientific Delft, Netherlands.

[13] Ojeh, V.N. (2011) Thermal Comfort Characteristics in Warri and Environs, Delta State, Nigeria. An Unpublished M.Sc. Dissertation in the Department of Geography and Regional Planning, Delta State University, Abraka.

[14] Olaniran, O.J. (2004) Physiological Climate of Ilorin. Journal of Environmental Psychological, 24, 17-30.

[15] Santin, O.G., Itard, L. and Visscher, H. (2014) The Effect of Occupancy and Building Characteristics on Energy Use for Space and Water Heating in Dutch Residential Stock. Energy and Buildings, 41, 1223-1232. https://doi.org/10.1016/j.enbuild.2009.07.002

[16] (2008) Energy Efficiency in Buildings in China: Policies, Barriers and Opportunities/Carmen Richerzhagen. In Collaboration with the Research Centre for Sustainable Development (RCSD) of the Chinese Academy of Social Sciences (CASS).

[17] Kats, G. (2006) Greening America's Schools Costs and Benefits. A Capital-E Report.

[18] Lenoir, A., Cory, S., Donn, M. and Garde, F. (2011) Users' Behaviour and Energy Performances of Net Zero Energy Buildings. 12th Conference of International Building Performance Simulation Association, Proceedings of Building Simulation, Sydney, 14-16 November 2011, 1527-1534.

[19] Efe, S.I. (2005) A Comparative Study of the Physiologic Comfort of Sapele, Warri and Onitsha of Nigeria. Illorin Journal of Business and Social Sciences, 13, 152-162.

[20] Atmaca, I., Kaynkli, O. and Yigit, A. (2007) Effects of Radiant Temperature on Thermal Comfort. Building and Environment, 42, 3210-3220. https://doi.org/10.1016/j.buildenv.2006.08.009

[21] Corgnati, S., Filippi, M. and Viazzo, S. (2007) Perception of the Thermal Environment in High School and University Classrooms: Subjective Preferences and Thermal Comfort. Building and Environment, 42, 951-959. https://doi.org/10.1016/j.buildenv.2005.10.027

[22] Ghisi, E. and Massignani, R. (2007) Thermal Performance of Bedrooms in a Multi-Storey Residential Building in Southern Brazil. Building and Environment, 42, 730-742. https://doi.org/10.1016/j.buildenv.2005.10.026

[23] Hoof, J.V. and Hensen, J.L.M. (2007) Quantifying the Relevance of Adaptive Thermal Comfort Models in Moderate Thermal Climate Zones. Building and Environment, 42, 156-170. https://doi.org/10.1016/j.buildenv.2005.08.023

[24] Liu, J., Yao, R. and McCloy, R. (2012) A Method to Weight Three Categories of Adaptive Thermal Comfort. Energy and Buildings, 47, 312-320.

https://doi.org/10.1016/j.enbuild.2011.12.007 
[25] Ho, S., Rosario, L. and Rahman, M. (2009) Three-Dimensional Analysis for Hospital Operating Room Thermal Comfort and Contaminant Removal. Applied Thermal Engineering, 29, 2080-2092.

https://doi.org/10.1016/j.applthermaleng.2008.10.016

[26] Memon, R.A., Chirarattananon, S. and Vangtook, P. (2008) Thermal Comfort Assessment and Application of Radiant Cooling: A Case Study. Building and Environment, 43, 1185-1196. https://doi.org/10.1016/j.buildenv.2006.04.025

[27] Adunola, A.O. (2011) Adaptive Thermal Comfort in Residential Buildings in Ibadan Metropolis. Unpublished Doctoral Thesis, Obafemi Awolowo University, Ile-Ife.

[28] Peeters, L. (2008) Thermal Comfort in Residential Buildings: Comfort Values and Scales for Building Energy Simulations. Applied Energy, 86, 772-780.

https://doi.org/10.1016/j.apenergy.2008.07.011

[29] Santamouris, M. (2010) Advances in Building Energy Research: Volume 4. Earthscan, London. https://doi.org/10.4324/9781849776349

[30] Lin, T., DeDear, R. and Hwang, R. (2010) Effect of Thermal Adaptation on Seasonal Outdoor Thermal Comfort. International Journal of Climatology, 31, 302-312.

http://onlinelibrary.wiley.com

https://doi.org/10.1002/joc.2120 